\title{
Um qualquer espectador: notas sobre um escândalo teatral
}

A given spectator: notes on a theater scandal

\section{Luiz Paulo Pimentel \\ Julio Groppa Aquino}

Luiz Paulo Pimentel

Mestrando na Faculdade de Educação da USP

Julio Groppa Aquino

Professor titular da Faculdade de Educação da USP

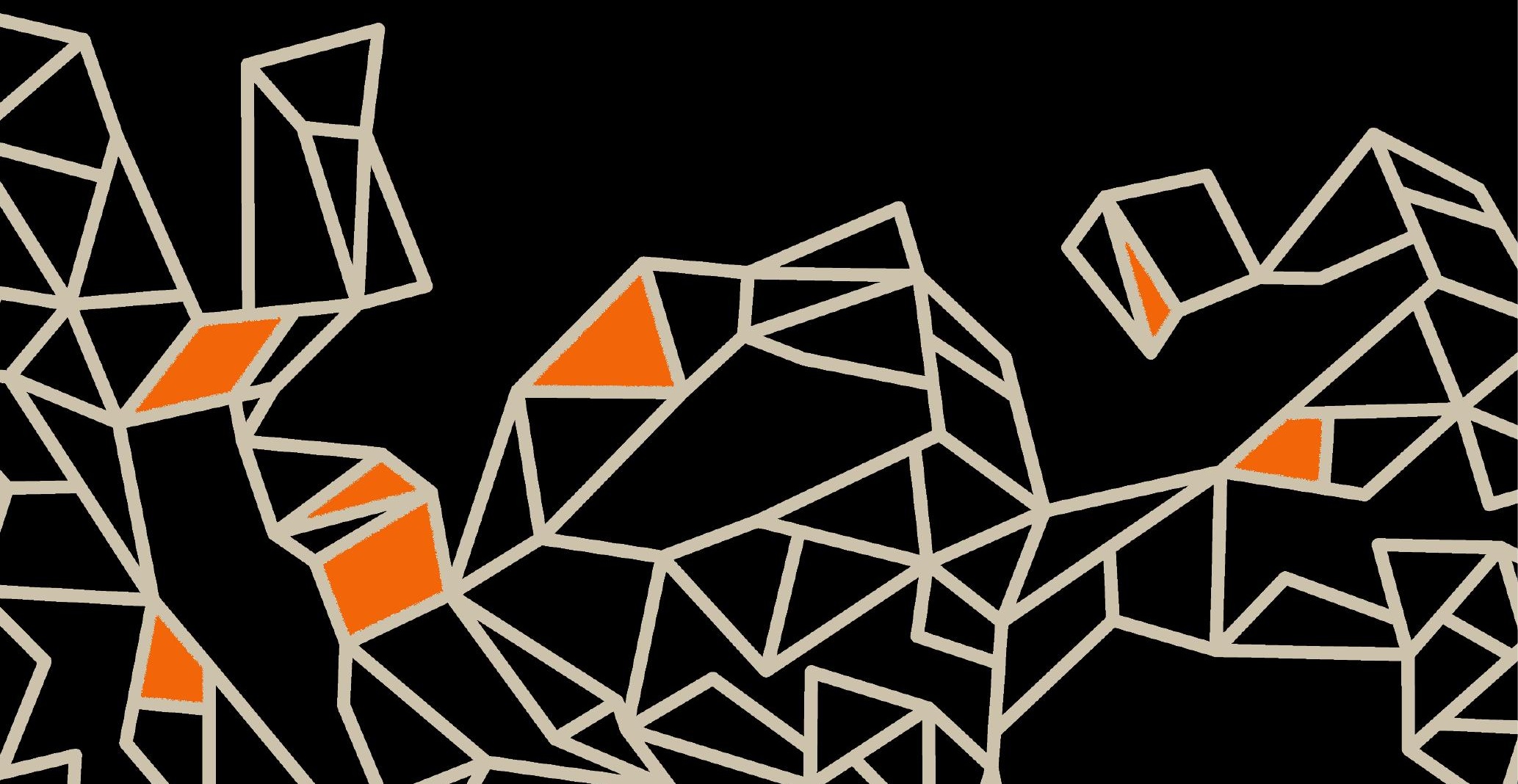




\section{Resumo}

O presente texto debruça-se sobre um escândalo teatral ocorrido em 1827, no Brasil, com vistas à análise da vinculação, centrada na figura do espectador, entre as práticas teatrais e certas políticas de Estado, por meio de estratégias pedagogizantes. Assim, investiga-se a emergência do espectador como sujeito de periculosidade, bem como de uma série de táticas de governo empenhadas em gerenciá-lo por meio do policiamento de seu corpo e da educação de seus hábitos, cujos efeitos insistiriam no presente.

Palavras-chave: História do teatro brasileiro, Espectador teatral, Pateada, Governamentalidade.

\section{Abstract}

The present paper approaches a theatrical scandal that happened in Brazil in 1827, aiming at analyzing the link, with focus on the spectator, between theatrical practices and certain State policies, through pedagogizing strategies. Thus, the appearance of the spectator as hazardous subject is investigated, as well as a series of governing tactics intended to manage this spectator by policing his/her body and educating his/her habits, whose effects would last until today.

Keywords: History of Brazilian theater, Theatrical spectator, Pateada, Governmentality.

O presente texto dedica-se a uma análise pontual do entrecruzamento histórico entre práticas teatrais e educacionais no Brasil, por meio dos deslocamentos atribuídos por tais relações ao corpo do espectador. Para cumprir esse propósito, pretende-se avizinhar três episódios ocorridos no país ao longo do ano de 1827, com destaque para um escândalo teatral. Os acontecimentos históricos são aqui perspectivados a partir de problemas contemporâneos concernentes às ligações entre teatro, política e educação.

A alusão a esses acontecimentos históricos, cabe enfatizar, enseja investigar pontos de semelhança e divergência radical em relação à situação a que o espectador teatral está submetido atualmente e suas possíveis formalizações pregressas. Entretanto, o recuo histórico aqui proposto não tem como 
fim forjar uma narrativa cujo objetivo seria recompor o que poderia vir a ser uma nova proposta para a historiografia oficial do teatro em relação aos comportamentos ou disposições dos espectadores ao longo de determinado arco temporal. Ao contrário, interessa escavar justamente as dessemelhanças, os desvios, as descontinuidades e as discrepâncias entre os regimes de verdade contemporâneos e os que circulavam na discursividade sobre o teatro na primeira metade do século XIX. Trata-se, fazendo eco ao procedimento arqueogenealógico proposto pelo pensador Michel Foucault (2008c), de investigar, em determinado ponto do tempo, a emergência de toda uma nova racionalidade que, de certa maneira, insiste na contemporaneidade.

Assim, o intuito do presente artigo localiza-se na problematização da centralidade da figura do espectador nos debates entre teatro e política contemporâneos, de modo a esboçar o caminho que fez com que tal personagem se vinculasse diretamente ao elo discursivo entre as práticas teatrais e educacionais na história brasileira.

Com 40 anos de idade, a soprano francesa Elisa Barbieri, quase desconhecida na Europa, desembarcou no Rio de Janeiro em setembro de 1827. Desde maio daquele ano, algumas campanhas em revistas e jornais que circulavam no país geraram grande expectativa quanto à sua chegada, produzindo certa aura mítica em torno da cantora. À estreia da artista, publicaram-se diversos comentários nos jornais confirmando a superioridade de sua performance em relação às demais líricas, adjetivando-a como angelical, graciosa e formosa, e elevando-a à posição de "a primeira de todas e, por isso mesmo, já não queremos outra primeira" (ASTRÉA, 1828, p. 2). Rapidamente, criaram-se partidos teatrais ${ }^{1}$ ao seu redor, rivalizando-a com outra soprano que já residia há muito tempo no país: a Fasciotti.

A peleja entre os partidos de espectadores de Fasciotti e os de Barbieri migrou também para os periódicos em circulação. De acordo com o pesquisa-

1 A divisão dos espectadores em partidos teatrais nas plateias do teatro brasileiro era comum ao longo de determinado período do século XIX. Os partidos organizavam-se ao redor de um ou outro artista e empenhavam-se em manifestar seu apoio com forte entusiasmo, muitas vezes provocando escândalos e brigas no próprio recinto teatral (FARIA; GUINSBURG; LIMA, 2009). 
dor Luís Antônio Giron (2004), as opiniões sobre as artes de espetáculo nas gazetas e a consequente troca de insultos entre os cronistas contrastavam com a linguagem polida de textos relativos ao cotidiano das cidades, fomentando, provavelmente, a curiosidade do público leitor assinante.

Os autores da Gazeta do Brasil, em geral espectadores diletantes letrados que se valiam das publicações para esboçar alguns movimentos críticos, passaram a se confrontar com os autores das revistas Astréa e O Espelho Diamantino, voltada para educação das mulheres. Os primeiros filiaram-se aos barbieristas, redigindo textos agressivos em relação à soprano rival. A Astréa, por sua vez, tomou o partido de Fasciotti, alegando que nada haveria de extraordinário em Barbieri. Ao longo da disputa, os textos não cessavam de afirmar que a mediocridade da soprano francesa se evidenciava pelo fato de ela nunca estar cercada pela melhor gente, sendo valorizada apenas pelos patuscos da plateia (Giron, 2004).

Curioso é o fato de que, em determinado momento da polêmica, um autor da Astréa tentou fustigar os admiradores de Barbieri ao indagar se a soprano não seria uma miragem que só tomaria forma aos olhos do pouco cultivado público brasileiro, incapaz de separar o joio do trigo. A própria divindade da cantora foi relativizada quando o autor questionou publicamente em razão de qual milagre seus encantos teriam sido escondidos até seus 40 anos. Segundo o autor, "em toda parte a chegada das cantoras divinas é anunciada pela trombeta da fama. Só este astro rutilante quis chegar entre nuvens, e bem espessas, para nos dar supressa de seu repentino luzimento! Quem não sabe que estas circunstâncias são as que acompanham sempre a mediocridade?" (ASTRÉA, 1828, p. 3).

Pode-se observar aí uma prática que começava a dar seus primeiros passos nesse período histórico, a qual se estendeu pelas décadas seguintes, chegando, de algum modo, até nós: a forja da possibilidade de um discernimento efetivo entre mediocridade e excelência como critério do ajuizamento artístico. Tratava-se, dessa maneira, de operar um novo sentido crítico não somente analítico, mas também prescritivo, que possibilitaria, em tese, fundamentar a diferenciação entre as pessoas de bom e de mau gosto, entre os melhores e os piores da plateia, entre os espectadores cultos e os chucros, assim como entre os talentos artísticos verdadeiros e os impostores. 
Essa série de parâmetros, quer-nos parecer, abria as condições de possibilidade para a emergência paulatina de algo que viria a ser a experiência da crítica teatral brasileira, experiência essa fundamental para a instauração do chamado moderno teatro brasileiro em meados do século XX (RAMOS, 1994).

Entretanto, é importante frisar a elasticidade característica dos critérios de verdade então em jogo à época do episódio aqui em destaque. A justa medida do legítimo versus ilegítimo na arte teatral ainda se encontrava em seus primeiros esboços. Além disso, tais parâmetros não cessavam de ser questionados por escritores, diletantes, fazedores de teatro e pelo próprio público em relação à sua validade. Dessa forma, lançar o olhar para um episódio lateral envolvendo uma soprano estrangeira recém-chegada ao Rio de Janeiro permite vislumbrar uma situação outra em relação à enunciação social do entendimento sobre o artístico em uma circunstância histórica em que os próprios critérios desse juízo começavam a se tornar problemáticos.

Em razão, talvez, desse jogo impermanente entre o verdadeiro e o falso no campo das artes de espetáculo, a revista O Espelho Diamantino - periódico de política, literatura, belas-artes, teatro e moda dedicado às senhoras brasileiras descreveu e, ao mesmo tempo, refutou o seguinte episódio acontecido em uma das representações da "ópera semi-séria" O califa e a escrava, estrelado por Barbieri:

Todas as folhas desta Corte têm falado nos escândalos que se têm praticado ultimamente no Teatro e das medidas enérgicas que têm a Polícia tomado para acabar com eles. Entretanto, não devem as pessoas que têm tido o objeto de semelhante brutalidade fazer dela mais conta do que merece, pois quando se encontra uma sala cheia de admiradores, que importa a uma cantora que um lacaio, um mariola, um moço de estrebaria, pago por alguns invejosos, atire cobre no Teatro? (O ESPELHO DIAMANTINO, 1827, grifo dos autores)

O fato é que, numa noite qualquer de apresentação de Barbieri, a atriz foi interrompida, ao longo de sua performance, por algumas moedas de cobre lançadas violentamente ao palco por alguém da plateia. Outro jornal descreve esse espectador impertinente como "um qualquer, de longas oreIhas, que jogou, diversas vezes, vinténs sobre a cena” (GIRON, 2004, p. 98, grifo dos autores). 
Esse singelo e ruidoso episódio é aqui trazido à baila com o intuito de evidenciar a permanente tensão que habitava as salas de espetáculo no Brasil do século XIX, assim como o comportamento desregrado de seus espectadores. Para tornar tal cenário mais visível, faz-se necessário examinar detalhadamente uma série de acontecimentos que um episódio como o dos vinténs permite cogitar sobre a situação das artes de espetáculo ao longo da transição entre o Império e a República.

Em primeiro lugar, é preciso pontuar que, nas salas de espetáculo de então, lacaios, mariolas e moços de estrebaria podiam ser encontrados junto a estudantes, nobres e policiais. Até meados do século XIX, por mais que os teatros fossem tidos como diversões elitistas, também o frequentavam, sob diversas circunstâncias, escravos, empregados braçais, famílias, crianças e pessoas pobres (RAMOS, 2012; GIRON, 2004). Essa espécie de convívio entre, de um lado, o Imperador e seu séquito e, de outro, os habitantes mais diversos da capital do país, tornava as plateias um espaço de intensas reverberações e de debates do cotidiano citadino. Tal cenário só começaria a ser efetivamente alterado com a criação do projeto moral e pedagógico do Teatro Ginásio Dramático, em 1855, cuja visitação era restrita a apenas determinada parcela dos habitantes da cidade, em geral a elite letrada (FARIA, 2012). O Ginásio também seria responsável por operar uma cisão entre um teatro considerado sério, ou seja, portador da verdadeira arte e socialmente necessário por excelência, e outro compreendido como ligeiro, visitado pelas camadas baixas da população.

Um segundo ponto passível de ser subtraído do episódio sob exame é a desconfiança do autor de O Espelho Diamantino a respeito da autenticidade do juízo desse espectador insurgente. Duvida-se se a afronta à atriz seria espontânea ou não, uma vez que o público era algumas vezes contratado para se manifestar contra certas apresentações (MACEDO, 1812). Entretanto, cabe notar que a autenticidade do gesto de atirar moedas de cobre à cena não é enunciada como algo suficientemente relevante para a descrição do episódio. $\mathrm{Na}$ realidade, parece não importar em absoluto o fato de o sentimento do espectador em relação à cena ser análogo, ou não, à sua motivação interna. O que se apresenta como questão são os sentidos propriamente públicos e coletivos da atitude de atirar objetos contra uma atriz, e não a fundamentação 
íntima de tal gesto. Dessa forma, a própria verdade do juízo e do gosto pessoal não se constituía como um problema para o pensamento crítico do período, pois ele se situava sempre de maneira pública e em sua superficialidade.

A terceira observação incide sobre a presença policial. Instituição recente no país, a polícia não tardou a entrar nas salas de espetáculo com o objetivo de conter comportamentos e manifestações tidas como inapropriadas ao longo das apresentações. Em seu estudo sobre a presença policial nos teatros do século XIX, Silvia Cristina Martins Souza (2005) descreve as atitudes disciplinares e pedagógicas dessa nova entidade instalada pela Corte, bem como a consequente estranheza em relação a ela por parte dos citadinos. Por ser uma instituição recém-formalizada no país, a intervenção policial nos teatros acabava gerando uma série de resistência por parte dos frequentadores das plateias. No episódio aqui analisado, a ineficiência policial em ser respeitada como autoridade parece ser evidente, pois os autores exigem maior policiamento e normas mais severas nas salas de espetáculo, sublinhando, dessa forma, a frequência com a qual escândalos aconteciam dentro dos teatros. Um episódio descrito algumas décadas adiante seguiria evidenciando quanto a instituição policial era ineficaz em produzir respeito à sua autoridade dentro e fora dos teatros.

A ideia caminha: o governo do povo pelo povo no teatro, eis o que os insurgentes querem! O subdelegado de nada vale, a autoridade pouco importa. O subdelegado lamenta a coisa, e, estribado na lei, dá parte do ocorrido ao delegado. Este apresenta-se em campo com a força suficiente para resistir a qualquer insulto feito à polícia. Ronca o trovão; a tempestade desencadeia-se, forte ao princípio, horrorosa no fim. Enquanto a pateada campeia sozinha, a impassibilidade é a norma de conduta adotada pelo delegado. De repente, uma batatada começa a se cruzar em diversos sentidos, ameaçando reduzir o rosto da atriz Sra. Suzana às proporções de um filet sanglant aux pommes sautées. $O$ delegado manda advertir os contraventores pelo comandante da força, o qual, como prêmio da advertência, recebe uma cadeirada pelas costas. Nasce o conflito. Os policiais travam do chanfalho, os insurgentes armam-se de balaústres e de parte a parte alguns ferimentos, embora ligeiros, mas lamentáveis em todo caso, vêm mostrar que a exaltação, onde quer que apareça, é sempre prejudicial. (A VIDA FLUMINENSE, 1872, s/p)

Por fim, pode-se ponderar como acontecimento fundamental aquele que reside na própria espinha dorsal do episódio dos vinténs: o embate entre uma 
cantora divinizada e um espectador infame ${ }^{2}$. Ou, mais especificamente, o inusitado embate entre uma cantora divinizada e um qualquer que questiona a veracidade do talento daquela. É importante relembrar que uma artista como Barbieri, ao mesmo tempo em que era adorada, estava também sob suspeita de ser um engodo e, justamente por ser objeto dessas duas opiniões, não havia consenso em relação a nenhuma delas. Assim, a verdade sobre a real natureza de seu talento era tanto afirmada como negada. Observe-se que não se trata, nesse caso, de nenhum meio-termo: não se tratava de uma indiferença em relação à atriz por parte de seus contestadores, e muito menos de uma aprovação com ressalvas por parte dos adoradores. Seu talento, ou seja, sua legitimidade artística, parecia comportar as duas qualidades ao mesmo tempo - o verdadeiro e o falso - no próprio calor de suas manifestações; isso só pôde ocorrer uma vez que duas forças discursivas o formalizavam dessa maneira e sem qualquer concessão.

Ora, essa ambivalência vivida era comum na vida de quase todos os artistas do palco do século XIX. Até mesmo grandes nomes que foram consagrados pela historiografia oficial das artes cênicas, como o ator João Caetano, foram pateados, sendo o caso mais extremo o do ator Eugenio Oyanguren:

A peça era a "Marina", uma tradução de Artur Azevedo. Um desastre. O Eugenio era xucro demais. A natureza só Ihe havia dado voz. Não sabia pisar, não sabia andar, não sabia sentar-se, não sabia o que fazer dos braços e das mãos. $E$ mais do que isso, quando falava, o seu espanhol era tão arrevesado que ninguém entendia patavina. Logo que o tenor entrou em cena, ou melhor, logo que ele começou a falar, rompeu a pateada na plateia. Foi com pateada que Eugenio Oyanguren iniciou sua vida teatral. Outro qualquer desanimaria, ele não. A pateada ia ser a companheira inseparável de sua carreira artística (A MANHÃ, 1945, s/p).

2 Alude-se, aqui, ao texto $A$ vida dos homens infames (FOUCAULT, 2003) que, de acordo com seu autor, trata-se de uma "antologia de existências" que só puderam chegar até a contemporaneidade porque, no momento histórico em que viviam, foram interpeladas pelo poder: "o poder que espreitava essas vidas, que as perseguiu, que prestou atenção, ainda que por um instante, em suas queixas e em seu pequeno tumulto, e que as marcou com suas garras, foi ele que suscitou as poucas palavras que disso nos restam; seja por se ter querido dirigir a ele para denunciar, queixar-se, solicitar, suplicar, seja por ele ter querido intervir e tenha, em poucas palavras, julgado e decidido" (p. 210). 
A pateada foi uma prática recorrente nos teatros brasileiros ao longo de quase todo o século XIX. Consistia em um movimento dos espectadores em oposição aos aplausos. Autor de um tratado sobre a prática da pateada, o padre português José Agostinho de Macedo (1812, p. 13), assim a descreve:

Pateada é um movimento espontâneo de pés, bordões, cacheiras, tábuas, assobios, feito na plateia pelos senhores espectadores de que resulta uma assoada, açougaria e matinada confusa dada nas bochechas aos cômicos para se lhes dizer com toda a civilidade que o que estão representando, ou acabam de representar, é uma completa parvoíce, uma manifesta pouca vergonha, ou um solene destempero.

O caso de Barbieri, está claro, não é de um rechaço tão extremo quanto o do exaustivamente pateado Oyanguren. Entretanto, a análise do episódio da afronta da soprano faz notar um movimento bastante singular em relação ao funcionamento do discurso artístico de seu tempo. É necessário observar que o posicionamento da intérprete nessa região tensa entre aceitação e recusa pública, entre especialista dos sentimentos e charlatã estrangeira, e, por fim, entre ser divino e mundano, acabaria por conferir a Barbieri um espaço inusitado de ação no que diz respeito a seu próprio fazer artístico. Se, por um lado, a artista assumia um lugar discursivo de destaque, ou seja, posicionava-se como uma soprano que deveria ser apreciada, aplaudida e respeitada, ela também precisava sustentar, ao longo de sua performance, a margem de uma estranha abertura para o aparecimento do exato avesso da validação de sua arte. Nomeia-se aqui essa espécie de posição como uma abertura ética, pois se tratava de certa disposição de jogo para que sua própria performance pudesse ser interpelada, dobrando-a para abrir mão de sua autoridade a qualquer momento e a um qualquer, dada a instabilidade de sua própria soberania, fragilmente traduzida em monopólio cênico. Isto é, justamente por sua autoridade ser ao mesmo tempo verdadeira e falsa, ela deveria estar sempre preparada para ser interrompida por qualquer pessoa que se dirigisse à sua figura na forma de provocação. Mais além, para poder ocupar sua posição como artista e obter algum sucesso em sua prática, ela era obrigada a correr o risco de se submeter cotidianamente a essa abertura para dois possíveis - a louvação e o rechaço -, pois, sem correr esse risco, ela jamais poderia encontrar sua glória. 
Não se deve presumir que Barbieri, ou qualquer artista da época, buscasse ou tivesse a intenção de se situar em tal posição ambivalente e, presumidamente, incômoda. Ao contrário, entende-se, aqui, que essa posição era uma circunstância proveniente dos próprios jogos de verificação e de normalização da arte de seu tempo. O que deve ser perspectivado é o fato de que a instabilidade dos critérios de ajuizamento artístico que ali se dava fazia a própria ideia de arte como força essencial e imutável gaguejar. Indo mais além, essa vulnerabilidade podia, como no caso em evidência, abolir a distância entre as duas posições, a do artista e a do um qualquer espectador, configurando entre eles, e em última instância, uma espécie de relação de perfeita equidade.

Antes de prosseguir, algumas observações sobre a referida relação de equidade se fazem necessárias. Esta, é evidente, não pressupõe uma posição de simetria social. O um qualquer do episódio dos vinténs não precisa ser um indivíduo respeitado para lançar os cobres à cena, e não há garantia de que se torne mais bem visto socialmente depois de fazê-lo. E é justamente por poder ocorrer na relação entre qualquer espectador e qualquer artista, sem distinção, que tal equidade aparece como uma abertura - ou uma disposição imanente - para o risco de um enfrentamento.

Como esse tipo de embate põe em xeque a própria autoridade da instituição artística, ele passa a instaurar, imediatamente, um campo de forças disruptivo. Logo, a equidade por ele cavada deve ser efêmera, pois, obrigatoriamente em sequência a ela, a verdade pesará sobre qualquer um dos lados, sendo reestabelecida de imediato uma nova e provisória regularidade. Por se tratar de algo circunstancial - uma pausa evanescente nos jogos de verdade em voga -, tal efemeridade necessita tomar corpo a cada noite de apresentação e em sua específica singularidade. Igualmente, por se tratar de algo oposto ao código consensual do aplauso - em geral, marcado por pouca variação -, as manifestações de ofensa lidam com a expectativa permanente de seu próprio acontecimento, sendo imprevistas e causando efeitos improváveis.

Deve-se notar também que a abertura para essa espécie de equidade entre cena e plateia raramente é deflagrada pelo artista, por mais que ele 
precise estar o tempo todo disponível para tal embate. Ao contrário, para que sua performance possa se dispor ao risco de interpelação, ele deve vincular-se ao discurso da arte que lhe confere legitimidade e distinção, pois, sem essa adesão incondicional, poderia ser criada uma zona de conciliação entre plateia e cena; uma zona, portanto, demasiado estável e sem risco. Daí que os espectadores e, nesse sentido, qualquer um deles, a partir do momento em que têm como oponente um artista vinculado à determinado regime de verdade de sua arte, devem arcar com a atitude de inverter o sentido da direção do jogo em andamento e enunciar uma verdade divergente daquela do artista.

Tal fato remete a outro ponto sobre essa equidade efêmera entre a autoridade do artista e a manifestação de um qualquer da plateia: não necessariamente a provocação do espectador será suficiente para colapsar a maquinaria teatral. Ao mesmo tempo, tal gesto pode sim causar a interrupção total do evento espetacular quando seu enunciado puder ser acolhido pelos outros espectadores e, portanto, disparar os humores alheios, gerando mais respostas que consintam com sua enunciação. Isso se deve ao fato de que o acontecimento de tal equalização só pode se dar em público, ou seja, o espectador insurgente deve contar com o risco de sua intervenção ser admitida, ou não, pelos outros que se situam na mesma posição do jogo na qual ele se encontra.

Uma vez que esse jogo só pode se dar publicamente, pouco interessa a verdade interior da opinião de cada espectador. Como já visto, as ações de enfrentamento dos espectadores não partiam necessariamente de algo que seria afeito à autenticidade de um ponto de vista, sendo, ao contrário, muitas vezem compradas ou orquestradas por terceiros ${ }^{3}$. Mesmo assim, esse fato não é suficiente para esmorecer o calibre do acontecimento em questão. Isso porque o jogo no qual essa equidade se manifesta é um jogo de superfície. Ou seja, é precisamente porque nessa batalha discursiva as posições são móveis e se manifestam apenas em sua superficialidade, delineando um cor-

3 Em seu tratado publicado em 1812, José Agostinho de Macedo listou sete tipos de pateadas distintas, desenvolvendo ainda, a partir de cada uma delas, diversas variações. Listamo-las: (a) pateada simples; (b) pateada mista; (c) pateada redonda; (d) pateada comprada; (e) pateada real; (f) pateada picada; (g) pateada rival. 
po de regras comuns aos jogadores, que todos deverão ter em conta que a qualquer momento o artista pode ser interpelado. E justamente porque as posições se manifestam superficialmente, o jogo pressupõe movimentos ágeis e inconstantes, pois os corpos que o jogam não precisam lidar com o peso de sua própria interioridade para se locomoverem entre as posições de aprovação e desaprovação.

Por esse motivo, o gesto de rechaço não pode ser pedagógico. Ou há triunfo e inversão do jogo de verdade que se praticava até então, ou não há nada. Não é possível existir, portanto, o acontecimento de uma aprendizagem comum: o espectador não interpela o artista de maneira a incitá-lo a um aperfeiçoamento de sua técnica, assim como o artista não se pronuncia tendo como objetivo educar os espectadores, movendo-os em direção a uma vida melhor. Trata-se apenas de refutar o que ali se apresenta como verdade, sem pretensões ulteriores.

Por fim, talvez o ponto fundamental a ser observado remete ao fato de que a abertura desse espaço de equalização entre cena e público estava condicionada a uma regra básica: para seu acontecimento, o espectador insurgente não poderia, sob hipótese alguma, ser um aliado do discurso formal da arte. É justamente por não operar no interior do repertório artístico que seu gesto se converte em força de interferência capaz de causar algum dissenso no plano discursivo teatral. É exatamente em razão de sua ignorância ou desconfiança em relação ao discurso da arte que o espectador se recusa a adentrar, mesmo sem querer, na posição de verdade assumida pelos artistas. Apenas por se tratar, de alguma forma, de um outsider da tradição discursiva do artístico é que sua potência de escândalo pode se realizar. É por fazer gaguejar o discurso de autoridade da arte que seu posicionamento em relação a um artista pode remeter ambos, imediatamente, a um estatuto efêmero e arriscado de equidade.

Para dar continuidade aos movimentos analíticos aqui dispostos, deve-se ter em mente o fato de que o episódio dos vinténs data de 1827. Em dezembro daquele ano, o intendente geral da Polícia da Corte do Império do Brasil, Francisco Alberto Teixeira de Aragão, foi responsável por baixar um edital com vistas a regular o funcionamento dos teatros e o comportamento do público popular 
(GIRON, 2004). A partir desse momento, era proibida a entrada nos teatros com armas, bengalas e chapéus, assim como a venda de produtos na plateia e a leitura espontânea de poemas por parte dos espectadores ao longo das apresentações. O decreto visava, assim, preservar o artista de qualquer atitude incômoda que pudesse ser-lhe dirigida pelo público. Por isso, também se proibiu a perturbação da "tranquilidade dos espectadores com vozerias ou estrépitos antes de se levantar o pano ou nos entreatos; durante a representação, fica livre mostrar moderadamente o prazer ou descontentamento pelo merecimento do espetáculo" (O SPECTATOR BRASILEIRO, 1827, p. 1, grifo dos autores).

Eficiente ou não, está claro que a presença policial nos teatros e sua tarefa de normalização dos comportamentos visavam conter as violências cometidas na relação público-cena. Essa presença também tinha como objetivo formar uma nova compreensão a respeito da figura do espectador teatral, que deveria ter hábitos cada vez mais docilizados. A instituição policial seria, dessa forma, uma força germinal para o rareamento dos escândalos teatrais ao longo do século XIX.

A segunda força ativa nesse processo operaria já não mais do ponto de vista de algo exterior e vertical, como uma legislação específica ou punição repressiva, mas como incitação a novas formas de convívio com as obras e os espaços teatrais. Tratar-se-ia, justamente, da produção de um sujeito espectador ilustrado por parte de uma discursividade edificante em relação ao universo da arte e da cultura.

Deve-se notar que 1827 guarda um acontecimento de razoável importância para a formação do moderno Estado brasileiro: inauguram-se as duas primeiras instituições de ensino jurídico do país. A primeira escola, situada em São Paulo, teve como lócus o antigo Convento de São Francisco (atual Faculdade de Direito do Largo de São Francisco), ao passo que a segunda foi sediada no Mosteiro de São Bento, em Olinda (atual Faculdade de Direito da Universidade Federal de Pernambuco). A novidade passaria não somente a reorganizar em larga medida o cenário político das duas cidades, como também relativizaria a necessidade de formação em Portugal por parte dos habitantes letrados do Império, formando, pela primeira vez na história, um corpo jurídico composto pela elite local (FIGUEIREDO; GOMES, 2012). Mais além, a formalização dos cursos jurídicos nacionais responderia de maneira eficaz 
às novas demandas em relação ao governo das condutas dos habitantes do país, demandas que vinham sendo deflagradas, com maior intensidade, desde 1808, com a instalação da Corte no Rio de Janeiro.

No que diz respeito ao crescimento da importância das instituições jurídicas na Modernidade ocidental, o pensador francês Michel Foucault observou que, a partir do século XVII, uma série de mudanças em relação às artes de governar teria sido operada pelos Estados europeus, engendrando uma nova forma de racionalidade política. Em alguns de seus estudos (FOUCAULT, 2008a; 2008b), o pesquisador debruçou-se sobre essa nova modalidade de gestão populacional engendrada pelos Estados modernos, e, dessas análises, forjou o conceito governamentalidade.

Segundo Edgardo Castro (2009, p. 190), o termo governamentalidade comportaria acepções complementares:

1) O conjunto constituído pelas instituições, procedimentos, análises e reflexões, cálculos e táticas que permitem exercer essa forma de exercício do poder que tem, por objetivo principal, a população; por forma central, a economia política; e, por instrumento técnico essencial, os dispositivos de segurança. 2) A tendência, a linha de força que, por um lado, no Ocidente, conduziu à preeminência desse tipo de poder que é o governo sobre todos os outros: a soberania, a disciplina, e que, por outros, permitiu o desenvolvimento de toda uma série de saberes. 3) O processo pelo qual o Estado de justiça da Idade Média converteu-se, durante os séculos XV e XVI, no Estado administrativo e finalmente no Estado governamentalizado.

Por meio do exame dos processos de governamentalização, Foucault dedicou-se a esquadrinhar o campo cruzado das matrizes normativas de comportamento, ou seja, passou a examinar as técnicas e procedimentos pelos quais foram se estruturando os esquemas de condução das condutas alheia e própria. A analítica foucaultiana, portanto, propõe uma atitude teórica que não se vale nem de ideias generalizantes ou da análise da história em termos de ideologia, mas de um modo de pensar mais afeito ao exame dos detalhes e da mutação de práticas cotidianas articuladas na relação entre governo de si e dos outros (FOUCAULT, 2010; 2011; 2014).

Claro está que, na esteira das investigações levadas a cabo por Foucault, todo o aparato jurídico, assim como suas instituições, regimes de ver- 
dade e atores sociais, despontam em alto relevo, precisamente por serem âmbitos privilegiados para o exercício de gestão das sociedades modernas. Sendo assim, o aparecimento de escolas jurídicas no Brasil recém-independente diz respeito a um período de produção de toda uma nova maquinaria de governo populacional. Trava-se, ao longo do século XIX, de forjar uma sociedade propriamente brasileira, a qual, fazendo uma aligeirada remissão ao título da obra Segurança, território e população, de Foucault (2008b), seria incitada a uma sucessão de novos dispositivos de governança apoiados nos problemas de segurança e disciplinamento social, de produção de modos de vida dentro dos limites da cidade e de um novo imperativo de governo: a gestão populacional.

É importante relembrar que a Faculdade de Direito do Largo São Francisco ao mesmo tempo em que seria responsável pela ilustração de parte significativa da elite intelectual brasileira no século XIX e do aperfeiçoamento das forças jurídicas nacionais, também formaria uma série de escritores, críticos e artistas teatrais, tais como José de Alencar, Castro Alves, Álvares de Azevedo, Paulo Eiró, Abadie Faria Rosa, Oswald de Andrade, Antônio de Alcântara Machado, Alfredo Mesquita, Décio de Almeida Prado, Clóvis Garcia, Miroel Silveira, Eudinyr Fraga, Paulo Autran, Ruy Affonso, Flávio Rangel, José Celso Martinez Corrêa, Renato Borghi, Carlos Queiroz Telles, Amir Haddad, entre muitos outros (VITOR, 2008). Ora, a historiografia oficial do teatro brasileiro (FARIA, 2001) considera como o primeiro tratado crítico do teatro nacional o texto Ensaios sobre a tragédia (RIBEIRO; ROCHA; QUEIROGA, [1833]2001), escrito justamente por três estudantes oriundos do Largo São Francisco. Dentre outros objetivos do ensaio, os estudantes meditavam sobre formas de tornar a cena mais passível de interesse ao espectador da época.

Assim, a emergência do gesto da crítica teatral, tal como esta se configura nos moldes contemporâneos, poderia ser aproximada, sem grandes riscos de generalização, da implementação da racionalidade jurídica no país. Renegando e bestificando o ser do público arruaceiro e elevando a arte ao estatuto de universal, uma série de enunciados passaria a circular nos periódicos, teatros e espaços de encontro do Brasil Imperial, os quais se esforçariam para forjar determinado homem de gosto pautado pelos ideais de discrição, 
de interesse e de moral. Tal produtividade seria solidária às tentativas oitocentistas de instauração de uma crítica teatral oficial no país. E tal movimento, que incitaria os habitantes do Império a partir de uma interioridade cultivada, operaria em seus corpos pronunciadas mudanças subjetivas. Essa espécie de movimento pedagogizante proposto pela crítica teatral resultaria de tal forma eficaz que faria com que as atitudes de enfrentamento dos espectadores em relação à cena fossem renegadas ou, no limite, internalizadas. O saldo de tal internalização seria cada vez mais a valoração da manifestação de um juízo civilizado emitido por uma multidão silente, respeitosa e moderadamente crítica em oposição ao teatro do escândalo ruidoso.

Sabe-se que não é recente o atual movimento das Artes Cênicas que vem delegando protagonismo à figura do espectador no interior das discussões entre teatro e política no Brasil. A revista Aspas organizou um dossiê reunindo textos a partir do mote $O$ espectador contemporâneo, corroborando tal diagnóstico. Lê-se em seu editorial:

Um fator que salta aos olhos é o crescimento desse campo de pesquisa [estudos sobre o espectador] nos últimos anos, que tem se dado de forma generalizada em praticamente todas as universidades do Brasil. Esse fato pode ser visto também como reflexo direto do número expressivo de trabalhos cênicos que trazem o espectador para a centralidade da criação, ao pensar a obra como algo que acontece, de forma cada vez mais intensa, entre público e cena. Nesse sentido, se o teatro já foi considerado, no decorrer das últimas décadas, como a arte do dramaturgo, do diretor e do ator, atualmente muitos o consideram a arte do espectador. (CARNEIRO; GUIMARÃES, 2016, p. 3)

De acordo com Flávio Desgranges, pesquisador dedicado às relações entre teatro, educação e espectador, o modo de produção de coletivos teatrais, nas últimas décadas, estaria deixando de se restringir às montagens de espetáculos, e redundando em algo que intitula espectador em processo. Parte dos artistas teria passado a convidar o público para integrar processos criativos ou a atuar em diversas outras frentes de trabalho, tais como oficinas, workshops, laboratórios de vivência etc. Segundo Desgranges (2012, p. 220), 
"as práticas propostas pelos grupos podem assumir um caráter formativo, ao possibilitar o acesso ao fazer teatral da parcela da população que pouco ou nada conhece do assunto".

De maneira análoga, políticas públicas vêm propondo a realização de monitorias, mediações de espetáculos e oficinas de iniciação à linguagem para a população em geral. Como exemplo dessa modalidade de ação, temos o extinto Programa de Formação de Público, situado na cidade de São Paulo, em 2001, que se encarregava de operar uma formação gradativa da população na linguagem teatral, "aprimorando sua capacidade de conceber um discurso teatral e de interpretar signos cênicos" (TENDLAU, 2010, p. 96).

Pode-se observar aí uma firme articulação discursiva entre teatro, educação e políticas governamentais, tendo como leitmotiv as relações entre os artistas e os espectadores. Nesse cenário, como afirmam os manifestos do movimento Arte Contra a Barbárie, organização de artistas responsável pela implantação da Lei de Fomento ao Teatro, as práticas teatrais deveriam ser consideradas como um espaço social tão fundamental quanto a educação, uma vez que se contraporiam à barbárie generalizada, resultante do sistema capitalista. O teatro, portanto, deveria ser considerado pelo movimento como responsável pela formação de cidadãos críticos (FARIA; GUINSBURG; LIMA, 2009).

A partir dessa fina articulação entre arte, educação, crítica social e cidadania, não parece gratuita a intensa circulação dos escritos sobre arte e política de Jacques Rancière no país. A edição brasileira de seu livro $O$ espectador emancipado foi lançada em 2012 e vem sendo largamente comentada por pesquisadores de diversos campos de pensamento das Artes Cênicas, como teatro-educação, pedagogia do espectador e teatro e política (CABRAL, 2012; DESGRANGES, 2008a, 2008b, 2011, 2012; MOSTAÇO, 2013; PUPO, 2015; SOARES; KASTRUP, 2015). Em geral vinculadas à aplicabilidade dos conceitos elaborados por Rancière com vistas a engendrar análises ou novas proposições artístico-pedagógicas, são poucas as pesquisas, no entanto, que partem da problemática formulada pelo pensador franco-argelino para interrogar o presente dos discursos artísticos e pedagógicos. Menos afeito à prescrição ou ao aconselhamento de formas mais propícias de gestão artística, Rancière afirma que, para que seja possível traçar alguma relação entre a ideia de emancipação intelectual e a questão do espectador nos dias de 
hoje, "seria preciso reconstituir a rede de pressupostos que põem a questão do espectador no cerne da discussão sobre as relações entre arte e política" (RANCIÈRE, 2012a, p. 8, grifo dos autores). Mais além, seria necessário descrever toda uma racionalidade veridictiva sobre a qual passamos a julgar as implicações políticas do espetáculo teatral, por meio da incidência de tal prática no corpo dos espectadores.

Assim sendo, a intenção do presente texto foi a de se vincular a uma problematização dessa natureza, reportando-se a uma atitude teórica experimental, cuja tentativa trataria de organizar um estranhamento em relação aos próprios discursos e regimes de veridicção que se desdobram no tempo presente. Trata-se, portanto, de experimentar fazer o presente resfolegar e, de alguma forma, perder o passo, atrasar-se um breve instante com o intuito de devolver algum pasmo em relação a seus lugares comuns discursivos.

Assim, se atualmente o problema da liberdade do espectador conecta-se a toda uma discursividade que culminaria em determinado ideal emancipatório, interroga-se, aqui, a premissa de que as margens dessa liberdade repousariam no cumprimento de um processo formativo de especialização do olhar do não-artista na linguagem teatral. Dessa maneira, a figura do um qualquer que poderia fazer tremer as estruturas do discurso da arte no século XIX, estaria, atualmente, enredada numa ampla teia formativa que, afinal, findaria por sufocar, quando não extirpar por completo, a potência disruptiva de seu gesto. Tal processo teria tido seu ponto de partida, como aqui está suposto, em toda uma política de regulação tanto dos recintos teatrais quanto da subjetividade dos espectadores, já em movimento desde meados do século XIX, com a emergência de algo como a crítica teatral.

Sabe-se que a evocação da necessidade de uma incursão prévia na linguagem artística por parte da população - e isso parece valer igualmente para outros campos artísticos além do teatro - não representa, de forma alguma, novidade. Entretanto, em nosso presente, a essa especialização formadora passa a ser conferida a conquista do ingresso de entrada definitivo não somente para o universo da cultura, mas sobretudo para a salvaguarda emancipatória dos sujeitos aí implicados. Assim transcorreria, em maior ou menor intensidade, o reclame educacional por parte das práticas teatrais contemporâneas, agora na chave enunciativa da liberdade, fundamentando todo 
um jogo de conversão do espectador desde e para a linguagem teatral, com vistas a alfabetizá-lo em uma série de pressupostos já estabelecidos a priori pelos artistas. Desde tal ponto de vista, educação e teatro confundem-se por completo quanto a seu papel e sua função no cenário das trocas sociais.

Seria possível, portanto, assistir à demanda por determinado espectador interessado e, portanto, obediente ao discurso da arte e da cultura, ao mesmo tempo e paradoxalmente, instado por esse mesmo discurso a se tornar um sujeito autônomo e livre. Tal seria o corpo visado não somente por muitos fazedores de teatro no Brasil contemporâneo, mas também por muitas políticas públicas alinhadas com programas de Estado: a demanda por um espectador cada vez mais eficiente e produtivo, convertido em um espectador crítico e cidadão.

A partir do diagnóstico aqui projetado, evoca-se a necessária suspensão, mesmo que temporária, da associação usual por parte dos discursos artísticos entre os termos arte e resistência. Vê-se que as práticas artísticas podem, mesmo sob a alcunha de revolucionárias, fomentar a lógica governamental corrente. Assim, mapeia-se um caminho tortuoso: da relação entre cena e público em permanente iminência de escândalo ao incentivo estatal para toda uma gestão populacional pautada no ideal de formação pela cultura. Ou, ainda, uma trama que se desdobra do corpo à alma do espectador. As práticas teatrais contemporâneas, em sua aposta pela conciliação e formação de público, estariam se projetando cada vez mais para fora da zona do risco do questionamento de sua própria legitimidade. Pautando-se como prática essencial, o teatro se concretizaria como elemento cultural de forte respeitabilidade, ao mesmo tempo em que perderia, paulatinamente, sua potência de escândalo e inversão dos jogos de verdade vigentes.

Talvez fosse proveitoso, uma vez mais, assumir a posição de um qualquer e lançar em direção à cena das práticas teatrais contemporâneas alguns materiais danosos, fazendo vacilar seus jogos de verdade.

\section{Referências bibliográficas}

ASTRÉA. Rio de Janeiro, n. 252, 28 fev. 1828.

CABRAL, B. Ação cultural e teatro como pedagogia. Sala Preta, São Paulo, v. 12, n. 1, p. 4-17, jun. 2012. 
CARNEIRO, L. M.; GUIMARÃES, J. Editorial - O espectador contemporâneo. Aspas, São Paulo, v. 6, n. 1, p. 1-6, 2016.

CASTRO, E. Vocabulário de Michel Foucault: um percurso pelos seus temas, conceitos e autores. Belo Horizonte: Autêntica, 2009.

DESGRANGES, F. Teatralidade tátil: alterações no ato do espectador. Sala Preta, São Paulo, v. 8, p. 11-19, 2008a.

. Mediação teatral: anotações sobre o projeto Formação de Público. Urdimento, Florianópolis, n. 10, p. 75-83, dez. 2008b.

O efeito estético: finalidade sem fim. Urdimento, Florianópolis, v. 12, n. 17, 2011.

A inversão da olhadela: alterações no ato do espectador teatral. São Paulo: Hucitec, 2012.

O ESPELHO DIAMANTINO. Rio de Janeiro, n. 6, 7 dez. 1827.

FARIA, J. R.; GUINSBURG, J.; LIMA, M. A. (Coord.). Dicionário do teatro brasileiro: temas, formas e conceitos. 2. ed. rev. e ampl. São Paulo: Perspectiva: Edições SescSP, 2009.

FARIA, J. R. (Org.). Ideias teatrais: o século XIX no Brasil. São Paulo: Perspectiva/ Fapesp, 2001.

. O teatro realista. In: FARIA, J. R. (Dir.). História do Teatro Brasileiro V. I. São Paulo: Perspectiva/Edições SescSP, 2012. p. 159-218.

FIGUEIREDO, M. C. C.; GOMES J. dos S. A origem dos cursos jurídicos no Brasil. Âmbito Jurídico, São Paulo, ano XV, n. 105, 2012.

FOUCAULT, Michel. Do governo dos vivos: curso no Collège de France (19791980). São Paulo: Editora WMF Martins Fontes, 2014.

A coragem da verdade: o governo de si e dos outros II: curso no Collège de France (1983-1984). São Paulo: Editora WMF Martins Fontes, 2011.

O governo de si e dos outros: curso no Collège de France (19821983). São Paulo: Editora WMF Martins Fontes, 2010.

. Nascimento da biopolítica: curso dado no Collège de France (1978-1979). São Paulo: Martins Fontes, 2008a.

Segurança, território e população: curso dado no Collège de France (1977-1978). São Paulo: Martins Fontes, 2008b.

Nietzsche, a Genealogia, a História. In: Ditos e escritos, volume II: arqueologia das ciências e história dos sistemas de pensamento. Rio de Janeiro: Forense Universitária, 2008c. p. 260-279.

A vida dos homens infames. In: Estratégia, poder-saber. Ditos e escritos IV. Rio de Janeiro: Forense Universitária, 2003. p. 203-222.

GIRON, L. A. Minoridade crítica: a ópera e o teatro nos folhetins da Corte: 18261861. São Paulo/Rio de Janeiro: Edusp/Ediouro, 2004. 
MACEDO, J. A. de. As pateadas de teatro investigadas na sua origem e causas. Lisboa: Impressão Régia, 1812.

A MANHÃ. Rio de Janeiro, n. 1190, 27 jun. 1945.

MOSTAÇO, E. Emancipação, a cena e o espectador em jogo. Sala Preta, v. 13, n. 12, p. 200-205, 2013.

PUPO, M. L. S. de B. Luzes sobre o espectador: artistas e docentes em ação. Revista brasileira de estudos da presença, Porto Alegre, v. 5, n. 2, p. 330-355, maio/ago. 2015.

RAMOS, L. F. A arte do ator e o espetáculo teatral. In: FARIA, J. R. (Dir.). História do Teatro Brasileiro V. I. São Paulo: Perspectiva/Edições SescSP, 2012. p. 137-158.

Da pateada à apatia: $O$ teatro da bagunça de Alcântara Machado e a crítica de teatro no Brasil. O Percevejo, Rio de Janeiro, v. 2, n.8, p. 48-51, 1994.

RANCIÈRE, Jacques. $O$ espectador emancipado. São Paulo: Editora WMF Martins Fontes, 2012a.

RIBEIRO, F. B.; ROCHA, J. J. da; QUEIROGA, A. A. de. Ensaios sobre a tragédia. In: FARIA, João Roberto (Org.). Ideias teatrais: o século XIX no Brasil. São Paulo: Perspectiva/Fapesp, 2001. p. 267-316.

SOARES, F. M.; KASTRUP, V. A experiência do espectador: recepção, audiência ou emancipação? Estudos e Pesquisas em Psicologia, Rio de Janeiro, v. 15, n. 13, p. 965-985, 2015.

SOUZA, S. C. M. Cada noite, cada lei: políticas públicas e teatro no Rio de Janeiro do século XIX. Dimensões - Revista de História da Ufes, Vitória, n. 17, 2005.

O SPECTADOR BRASILEIRO. Rio de Janeiro, n. 65, 3 dez. 1827.

TENDLAU, M. Teatro vocacional e a apropriação da atitude épica/dialética. São Paulo: Hucitec, 2010.

A VIDA FLUMINENSE. Rio de Janeiro, n. 254, 9 nov. 1872.

VITOR, M. da C. Teatro na São Francisco. Um mergulho na história. Revista da Faculdade de Direito, Universidade de São Paulo, São Paulo, v. 103, p. 1115-1126, jan. 2008.

Recebido em 01/03/2017

Aprovado em 26/04/2017

Publicado em 17/07/2017 